\title{
Suitability of Local Resource Management Practices Based on Supernatural Enforcement Mechanisms in the Local Social-cultural Context
}

\author{
Masatoshi Sasaoka $^{l}$ and $\underline{\text { Yves Laumonier }}^{2}$
}

\begin{abstract}
Environmental anthropological studies on natural resource management have widely demonstrated and thematized local resource management practices based on the interactions between local people and supernatural agencies and their role in maintaining natural resources. In Indonesia, even though the legal status of local people's right to the forest and forest resources is still weak, the recent transition toward decentralization presents a growing opportunity for local people to collaborate with outsiders such as governmental agencies and environmental nongovernmental organizations in natural resource management. In such situations, in-depth understanding of the value of local resource management practices is needed to promote self-directed and effective resource management. Here, we focus on local forest resource management and its suitability in the local socialcultural context in central Seram, east Indonesia. Local resource management appears to be embedded in the wider social-cultural context of the local communities. However, few intensive case studies in Indonesia have addressed the relationship between the Indigenous resource management practices closely related to a people's belief in supernatural agents and the social-cultural context. We illustrate how the well-structured use of forest resources is established and maintained through these interactions. We then investigate how local resource management practices relate to the social-cultural and natural resources context of an upland community in central Seram and discuss the possible future applications for achieving conservation.
\end{abstract}

Key Words: forest management; game resources; hunting; local resource management; local social-cultural context; Seram; supernatural enforcement mechanism

\section{INTRODUCTION}

Environmental anthropological studies on natural resource management have thematized local resource management practices based on supernatural enforcement mechanisms, $i$. e., whereby people believe that supernatural agencies such as ancestor spirits and natural spirits monitor human conduct and impose punishments on violators, promoting compliance with the rules. For example, Colding and Folke (2001) conducted a wide literature review on social taboos guiding human conduct toward the natural environment, referred to as resource and habitat taboos (RHTs), and compared RHTs in many places around the world to contemporary measures of conservation. Their review reveals that some RHTs supported by supernatural enforcement mechanisms have functions similar to those of formal institutions for nature conservation. An extensive literature review conducted by Hamilton (2002) classifies cases in which trees, groves, and forests are protected because of their sacredness or evil power and discusses the importance of metaphysical constraints in the conservation of biodiversity and culture. Bhagwat and Rutte (2006) also present evidence of conservation traditions at natural sacred sites around the world. They indicate that it is necessary to incorporate natural sacred sites into existing protected area networks, focusing on current threats to sacred sites such as legal ownership denying customary rights, population growth, increasing immigration, and the influence of westernized urban cultures.
In addition, several case studies of local resource management based on the supernatural enforcement mechanism have been published such as the following examples. Byers et al. (2001) examined the role of traditional religious beliefs and leaders in conserving remnant patches of a unique type of dry forest in northern Zimbabwe. Virtanen (2002) investigated the social-cultural basis of sacred forest institutions continuously functioning at the juncture of changing state laws and customary laws on the basis of a Mozambique case study. Saj et al. (2006) assessed the extent to which traditional hunting taboos on the colobus monkeys complement the formal nature conservation agenda. Etiendem et al. (2011) assessed local beliefs associated with the Cross River gorilla and taboos against hunting and eating of the gorilla in Cameroon and then discussed the usefulness of incorporating such beliefs and practices into the conservation of the species.

In Indonesia also, several case studies have focused on local resource management practices based on supernatural enforcement mechanisms. For example, Wadley and Pierce Colfer (2004), who conducted field research on human ecology in West Kalimantan, revealed that sacred forest patches (the sites of human death or burials and those claimed to be inhabited by nonhuman spirits) are important for wildlife and, as a result, are important game sources. Kanto (2008), who analyzed the relationship between adat land (customary land managed by adat law) and the local belief in divinities that are believed to dwell in the land, revealed that such belief 
contributes to the preservation of the land by prohibiting the local people transferring the land to outsiders and by upholding the legitimacy of adat law regulating land and resource use. Riley (2010) examined how the Tonkean macaque is situated in the folklore of villagers under study in central Sulawesi and revealed that, for many local villagers, the folklore has resulted in a taboo preventing them from harming the macaques, despite the frequent crop-raiding behavior of the species.

The reformation movement, which has been taking place in Indonesia since late 1998 after then-President Soeharto's fall, has stimulated the growth of a new perception of indigenous peoples in the country. The 1945 Constitution, which was amended between 1999 and 2002, now recognizes the existence of adat law (customary law) communities (indigenous societies) and their rights when they do not conflict with national interests (the development goals of the nation as a whole; Moniaga 2007). In 1999, Forest Law 41/1999 replaced the Basic Forestry Law. The 1999 law created a new forest category, hutan Adat or customary forests, defined as "state forests located in traditional jurisdiction areas" (Moniaga 2007:280). According to the law, therefore, customary forests are state forests where the state might allow limited use for the customary community (Moniaga 2007).

Even though the legal status of local people's right to the forest and forest resources is still weak, the recent transition toward decentralization presents a growing opportunity for local people to collaborate with outsiders such as governmental agencies and environmental nongovernmental organizations in natural resource management. In such situations, in-depth understanding of the value of local resource management practices is needed to promote self-directed and effective resource management.

Our study focuses on local forest resource management and its suitability in the local social-cultural context in central Seram, east Indonesia. Local resource management appears to be embedded in the wider social-cultural context of local communities (Berkes 2008). However, few intensive case studies in Indonesia have addressed the relationship between the local resource management practices closely related to a people's belief in supernatural agents and the social-cultural context. Therefore, we illustrate how the well-structured use of forest resources, including game animals, is established and maintained through these interactions. Then, we investigate how local resource management practices relate to the socialcultural and natural resources context of an upland community in central Seram and discuss the possible future applications for achieving conservation.

\section{METHODS}

\section{Research site}

The field research was conducted intermittently during 20032010 in an upland community given the fictitious name of
Amani oho. The village is in the forest interior of central Seram (Fig. 1). In 2010, the population of Amani oho was approximately 320 (59 households). Because there is no navigable roadway, it is necessary to walk to the coastal area where markets are situated. On foot, the journey from Amani oho to the north coast takes 2-3 days, whereas the journey to the south coast takes 1 day.

Fig. 1. Study site.

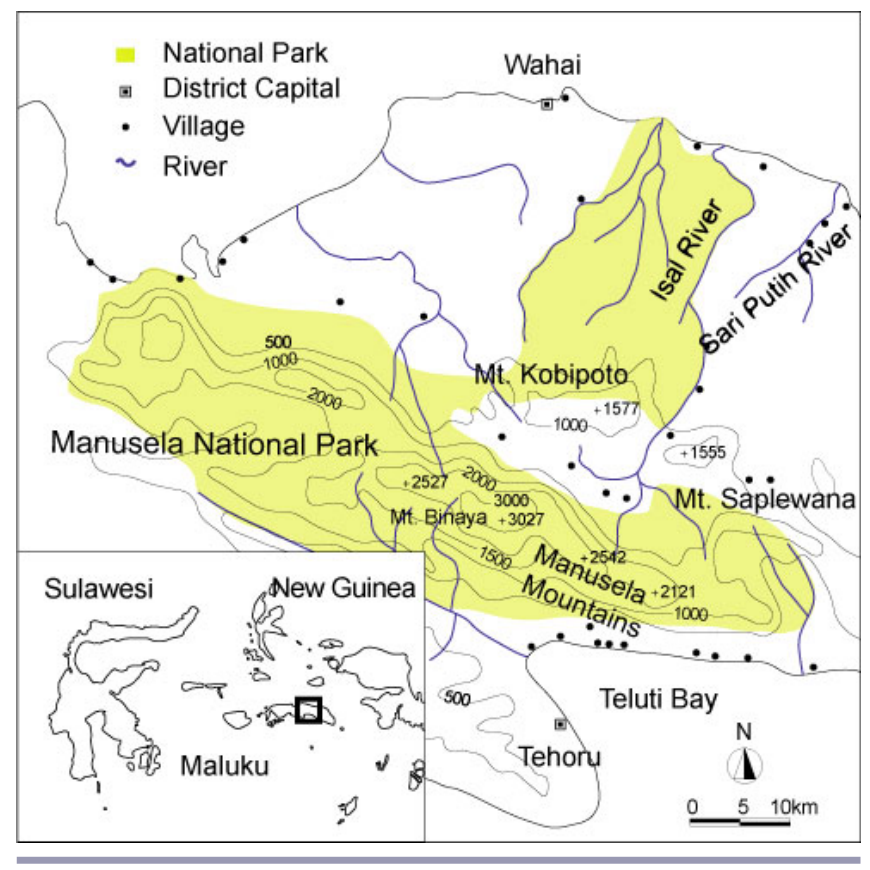

The main economic activities include sago extraction, banana and root crop agriculture, hunting and trapping, and gathering forest products such as edible plants, rattan, and wild honey. These activities are primarily conducted for subsistence. The villagers also engage in seasonal migrant work such as harvesting cloves in the southern coastal area during September-November and also occasionally sell nontimber forest products such as parrots and honey in the coastal areas (Sasaoka 2008a).

Local people are highly dependent on sago (starch extracted from the sago palm) as a staple food that is rich in carbohydrate but contains little protein (Sasaoka 2006). Game animals such as cuscus (Phalanger orientalis, Spilocuscus maculates), Celebes wild boar (Sus celebensis), and Timor deer (Cervus timorensis) are therefore essential sources of protein (Sasaoka $2008 b$ ). Hunting and trapping are usually conducted in a primary and mature secondary forest, far from the village. The forest area has been divided into many small forest lots on the basis of trails and natural landmarks such as rivers.

Manusela National Park (189,000 ha), in central Seram, was established in 1989. In the mid-1990s, approximately 32,000 
Table 1. Forest lot categories.

\begin{tabular}{|c|c|c|c|c|c|c|}
\hline & \multicolumn{5}{|c|}{ Type of forest lot } & \multirow[b]{2}{*}{ Total } \\
\hline & $\begin{array}{c}\text { Lohuno forest } \\
\text { (kaitahu lohuno) }\end{array}$ & $\begin{array}{c}\text { Soa forest } \\
\text { (kaitahu soa) }\end{array}$ & $\begin{array}{l}\text { Kin-group forest } \\
\text { (kaitahu keluarga) }\end{array}$ & $\begin{array}{l}\text { Private forest } \\
\text { (kaitahu } \\
\text { perorangan) }\end{array}$ & Discrepant $\dagger$ & \\
\hline $\begin{array}{l}\text { Number of forest } \\
\text { lots }\end{array}$ & 8 & 48 & 133 & 63 & 5 & 257 \\
\hline $\begin{array}{l}\text { Percentage of } \\
\text { forest lots }(\%)\end{array}$ & 3.1 & 18.7 & 51.8 & 24.5 & 1.9 & 100 \\
\hline
\end{tabular}

$\dagger$ Forest lots with disputed tenure status.

people lived in this area (Balai Taman Nasional Manusela: http://www.balaitnmanusela.org/profile_keadaanSosial1.htm). The nearest boundary of the park is approximately $2 \mathrm{~km}$ from the village. Nearly half the territory of Amani oho is inside the park, and most of the village's hunting and trapping grounds are located in the park. Current Indonesian law prohibits hunting and trapping inside national parks. However, weak law enforcement enables local people to continue catching game animals inside the park.

\section{Data collection}

Author Masatoshi Sasaoka collected data using Indonesian and the local language, Sou Upa, without an interpreter. The following four research methods were used.

- Key informant interviews on norms relating forest tenure and use: We conducted in-depth interviews intermittently during 2003-2010 with key informants, including the village head and members of the village council. The purpose was to obtain information on customary forest tenure arrangements; other norms to control forest use, including customary prohibition of forest use; and local people's view of the supernatural world.

- Household interviews on forest tenure status and imposition of temporary bans on forest use: In 2003, we conducted one-on-one interviews with all heads of households in Amani oho. These covered the tenure status of each forest lot, whether or not temporary hunting and trapping bans were in place, and who conducted hunting and trapping if a forest lot was used for those purposes. In 2004, we also conducted household interviews with 15 heads of household on the history of using forest owned by others.

- Group interviews on forest tenure status, rights of inheritance and transfer history, and conditions of forest use: We carried out group interviews in 2003 and 2004 with village elders from 10 of the 11 soa (patrilineal descent groups) to clarify the tenure status of all forest lots and their inheritance and transfer history. Villagers from Ilela poto soa, who have recently immigrated from the neighboring community, do not own forest within the territory of Amani oho. Therefore, they were not involved in the group interviews.

- Participatory forest mapping: A forest map was drawn through 4 days of participatory mapping in 2003. The 34 participants marked the location of each forest lot on a blank map, with only mountains and rivers indicated, through group discussion.

\section{RESULTS}

\section{Norms in controlling forest use and their social- ecological functions}

\section{Customary forest tenure}

The forest area in Amani oho is divided into 257 forest lots (kaitahu). Each lot has a specific name based on its topographic characteristics and belongs to a certain individual or group. Ownership here does not mean total ownership (absolute and exclusive rights), but rather relative and nonexclusive rights, as we describe later. The ownership of forest land is inherited through the paternal line.

Forest lots can be classified into four categories: lohuno forest, collectively owned by members of more than two soa; soa forest, owned by all members of a soa; kin-group forest, owned by several people related to each other through patrilineal kinship or other family ties; and private forest, owned by an individual (Table 1). In collectively owned forest (e.g., lohuno, soa, and kin-group forest) generally, members of the ownership group take turns using the forest, with an interval of several years during which the forest is closed for hunting and trapping.

Each collectively owned forest has a custodian (maka saka), who is expected to coordinate forest use. He is also regarded as understanding the history of forest rights inheritance and transfer and is eligible to talk about the history. Others strongly avoid talking about this because it is believed that if their account is incorrect, it will arouse the anger of ancestor spirits and hasten their death. 
Table 2. Forest lot categories according to forest rights inheritance and transfer history.

\begin{tabular}{|c|c|c|}
\hline Type of forest lot & Description & $\begin{array}{l}\text { Number of } \\
\text { forest lots }\end{array}$ \\
\hline Kaitahu mutuani & Forest inherited through patrilineal lines from generation to generation & 180 \\
\hline Kaitahu nahunahui & $\begin{array}{l}\text { Forest given gratuitously by the right-holding individual or a group that obtained some } \\
\text { support or aid in return for it }\end{array}$ & 22 \\
\hline Kaitahu katupeu & $\begin{array}{l}\text { Forest given by a person who was injured or came down with an illness in a forest or by the } \\
\text { relatives of a person who died in the forest to the person or people who carried the injured } \\
\text { or sick person or the dead body to the village }\end{array}$ & 4 \\
\hline Kaitahu helia & $\begin{array}{l}\text { Forest gifted by the bride's side to the groom's side as a return gift for a majority of the } \\
\text { bride's price }\end{array}$ & 10 \\
\hline Kaitahu fununui & Forest given gratuitously by the bride's father, brother, or relatives of the bride & 7 \\
\hline Kaitahu tohutohu & Forest purchased with old ceramic dishes, textiles, and money & 21 \\
\hline Kaitahu alasihata/rela & $\begin{array}{l}\text { Forest confiscated from a man who commits adultery with a married woman, or from his } \\
\text { father, brother, or relatives, as a fine. The confiscated forest right is granted to the husband } \\
\text { of the woman }\end{array}$ & 5 \\
\hline Kaitahu tukar & Forest exchanged between two forest ownership groups & 2 \\
\hline Total forest lots & & $251 \dagger$ \\
\hline
\end{tabular}

$\dagger$ Of the 257 forest lots that were listed in the field research, the tenure of 1 remained unclear because we were not able to interview the ownership group, and 5 forest lots had disputed status.

The forest is also classified into eight categories on the basis of the history of forest rights inheritance and transfer (Table 2).

When they become aware that death is approaching, the forest custodian (or the owner of private forest) leaves a message, known as itinau, concerning how the forest should be inherited. If they are unable to leave an itinau because of sudden death, the forest is inherited by the owner's male descendants (sons or nephews). An itinau is not only a message to people who live in the real world but also a message or declaration to the ancestor spirits.

In transferring a forest to a successor, the custodian or owner has to hand down orally the history of forest rights inheritance and transfers, the names of the natural spirits dwelling in the forest, and the itinau left by a previous custodians or owners.

\section{Social arrangements for nonexclusive forest use}

Villagers can hunt or trap in forest they do not own if they obtain permission from the owner. Forest owners rarely reject such requests because such rejection is considered shameful. Furthermore, the owner risks retribution from the ancestor spirits of the rejected party, which may cause their own attempts at hunting and trapping to fail, or they or their family to fall ill (Sasaoka 2008b). However, if the forest has been closed for hunting to allow the population of game animals to recover, the owner can ask the requester to refrain from using the forest for the time being; this gentle rejection is socially acceptable.

Based on the results of the one-to-one interviews on forest use, 40 of the 59 households $(68 \%)$ in Amani oho engaged in hunting and trapping in their own forests, and 14 households (35\%) used the forest of others (Table 3). According to the research on the history of forest use, most people continuously used the forest of others because they did not have their own forest; this included forests of the forest ownership group to which they belonged (Table 4). In 3 of the 14 households who used the forest of others, they engaged in hunting and trapping in forests owned by distant relatives or nonrelatives, whereas 11 households used forest owned by relatives tied by blood relationships to the maternal line or other conjugal relationships.

In practice, the forests of Amani oho are only partially open to nonrights holders, with owners controlling access. Villagers have a tendency to use the forest of close relatives because they hesitate to ask distantly related kin, with the exception of close friends. In addition, forest owners do not always accept requests from nonrights holders to use their forest.

\section{Temporary ban on hunting and trapping}

When the number of game animals declines significantly, a temporary ban on hunting and trapping, known as seli kaitahu, is imposed to allow the numbers to recover. All traps are removed from the forest, and a sign is set up made of wooden stakes. This is an object to which sira tana (natural spirits that raise and protect Celebes wild boar and Timor deer) and $a w a$ (natural spirits that raise and protect cuscus), and ancestors' spirits, mutuaila, are drawn or summoned temporarily. Local people believe that these spirits live in the forest and grant game animals as gifts.

After setting up the sign, the person who imposes the seli kaitahu lays offerings such as tobacco at the base of the sign 
Table 3. Nonexclusive forest use.

\begin{tabular}{|c|c|c|c|}
\hline Type of household use & Group and forest types & Number & Proportion $(\%)$ \\
\hline \multirow[t]{7}{*}{ Households using only their own forest } & Kin-group forest & 10 & \\
\hline & Soa forest & 7 & \\
\hline & Private forest & 6 & \\
\hline & Kin-group forest and private forest & 1 & \\
\hline & Lohuno forest and soa forest & 1 & \\
\hline & Soa forest and kin-group forest & 1 & \\
\hline & Subtotal & 26 & 59 \\
\hline \multirow[t]{4}{*}{ Households using only the forest of others } & Private forest & 5 & \\
\hline & Kin-group forest & 4 & \\
\hline & Soa forest & 3 & \\
\hline & Subtotal & 12 & 27 \\
\hline \multirow[t]{3}{*}{$\begin{array}{l}\text { Households using their own forest and the } \\
\text { forest of others }\end{array}$} & $\begin{array}{l}\text { Their own kin-group forest and the soa forest of } \\
\text { others }\end{array}$ & 1 & \\
\hline & $\begin{array}{l}\text { Their own soa forest and the private forest of } \\
\text { others }\end{array}$ & 1 & \\
\hline & Subtotal & 2 & 5 \\
\hline Total & & 40 & 91 \\
\hline
\end{tabular}

and calls the spirits by murmuring their names. He informs them of the ban and asks them not to provide game to anyone entering the forest to hunt in violation of the seli kaitahu (Fig. 2). In addition, they pray for any violator to receive misfortune, and for the game populations to recover.

Fig. 2. A villager conducts a ritual to impose seli kaitahu.

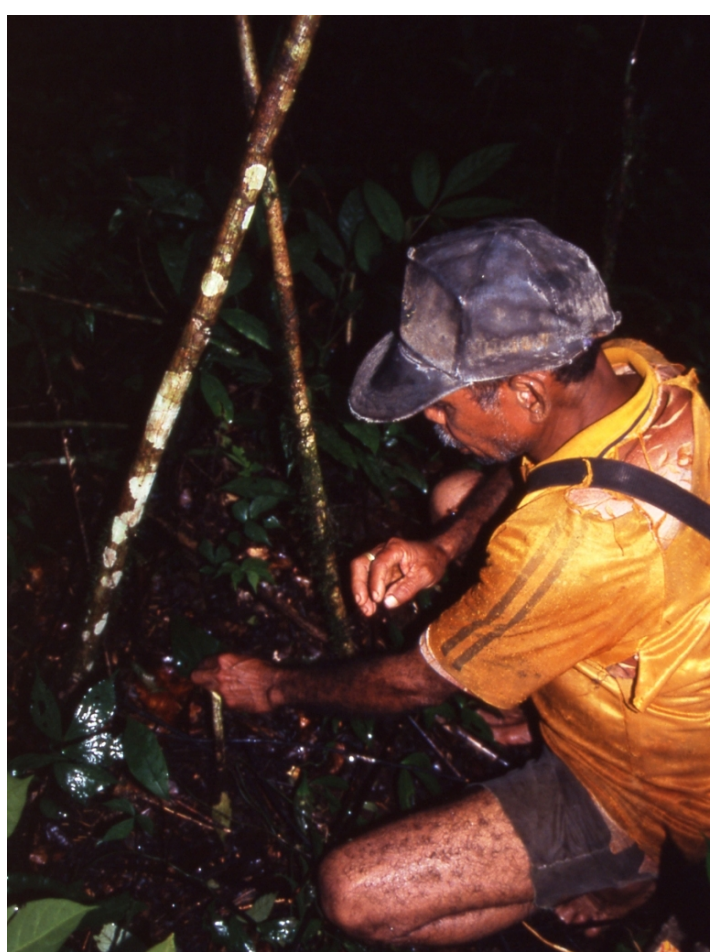

After the ritual is completed, no one, including the owner and the person who imposed the seli kaitahu, can trap or hunt in that area until the numbers of forest game recover. The villagers strongly believe that if they violate the seli kaitahu, they or their family members will meet with misfortune because of the sanctions imposed by the spirits.

Several years later, the person who imposed the seli kaitahu and/or the person who wants to hunt or trap in the forest visits the area to determine if the game has recovered based on the number of animal tracks and markings. If the number of game animals seems to have recovered, the seli kaitahu is lifted through prayer to the spirits made in front of the sign. However, if traps set in the forest do not catch much game, the forest may be closed by re-imposition of the seli kaitahu.

As of July 2003, 203 of the 257 forest lots (79\%) were subject to seli kaitahu (Table 5, Fig. 3). The villagers were hunting and trapping in 40 forest lots. Another three forest lots were not being used, even though no ban was imposed, and there were another eleven forest lots whose status we could not determine. Among forest lots with a hunting ban in place, 34 lots had been closed entirely for more than 20 years. These areas seem to be functioning as de facto sanctuaries. In most cases, these long prohibitions were based on the belief that these areas contain evil spirits who try to make hunters fall from trees, get injured by machetes, or become lost in the forest.

\section{Supernatural enforcement mechanisms in transition}

Narratives concerning violations of seli kaitahu

Belief in supernatural agencies plays an important role in local people's conformity to the norms controlling forest use. We now focus on the enforcement mechanism of seli kaitahu, the 
Table 4. Differences in the scale of forest tenure.

\begin{tabular}{|c|c|c|}
\hline Household & Forest tenure index $\dagger$ & Use of others' forest $\ddagger$ \\
\hline A. E. & 8.8 & + \\
\hline Ym. A. & 7.9 & - \\
\hline D. A. & 6.6 & + \\
\hline P. A. & 6.4 & - \\
\hline T. Mh. & 5.5 & - \\
\hline Yp. A. & 3.7 & - \\
\hline M. E. & 3.3 & + \\
\hline Y. Li. & 2.8 & + \\
\hline E. Li. & 2.7 & + \\
\hline B. La. & 2.3 & - \\
\hline F. E. & 2.0 & + \\
\hline A. My. & 1.5 & + \\
\hline D. My. & 1.3 & + \\
\hline L. Li. & 1.3 & + \\
\hline F. Li. & 1.0 & + \\
\hline
\end{tabular}

$\dagger$ Forest tenure index is defined as $\Sigma(1$ /number of households composing a forest ownership group).

$\ddagger$ Households that had used others’ forest for the past 10 years (+); households that had never used others’ forest (-).

hunting and trapping ban. Through narratives about the violation of seli kaitahu, we explore how the reality of supernatural agencies and their power is constructed.

Most villagers seem to have a strong belief in the power of supernatural agencies such as ancestor and forest spirits, and comply with the seli kaitahu. As illustrated in the following case stories, however, these beliefs do not mean that the ban is never violated.

Case 1: One day in 2006, D. A. (informant's initials) was setting traps in an area of forest for which the seli kaitahu had just been lifted when he discovered obvious signs that someone had been hunting in violation of the ban. The forest was collectively owned by D. A. and two of his cousins, and they had imposed the seli kaitahu for approximately five years. D. A. knew that another villager had hunted in the adjoining forest half a year before the ban was lifted and assumed that the man had crossed the forest border to hunt. D. A. did not report the infringement to the customary law authorities because the poacher could not be identified for sure and relationships among villagers might be strained. However, D. A. believed that it would only be a matter of time before supernatural agencies would bring misfortune to the infringer. Approximately six months later, the wife of that man experienced extremely hard labor in childbirth, which D. A. believed to be punishment from the spirits. (Interview with D. A., a 33-year-old male, in February 2007).

As this case illustrates, the agents expected to monitor forest use and punish violations of seli kaitahu are not people but supernatural agencies such as ancestor and forest spirits.
Other narratives about violations of seli kaitahu told by the villagers have a similar structure. Among them is the following narrative about the death of a man in the forest in 1986. This story is frequently referred to by the villagers as an example of the misfortune that will come to those who break the hunting ban.

Case 2: One day, while hunting in the forest, A. Li and Z. A. crossed into an area closed by seli kaitahu. A. Li found a cuscus hiding in a deep tree hollow. To catch the cuscus, he cut down the tree, but as the tree fell, vines twined around the trees pulled the next tree down, crushing A. Li to death. The head of Amani oho, Ym. A., and a village elder, F. Li., said that if they had asked for the seli kaitahu to be removed, A. Li would never have had such an accident. (Interviews with Ym. A., a 63-yearold male; F. Li., a 71-year-old male; and Ad. Li, a 50-yearold male, in January 2004).

In Amani oho, the acts of supernatural agencies play a significant role in their interpretation of the causes of misfortune. While staying in the village, one of the authors (Sasaoka) witnessed many events that could be regarded as misfortunes, from machete injuries to the sudden death of a young villager. Every time someone encountered a misfortune, the villages constructed a narrative about the family's conduct that would have incurred the displeasure of supernatural agencies. In this way, the reality of the supernatural agencies appears to be reinforced.

Recent transitions in forest resource management

Judging by how rare infringement of seli kaitahu is, people's belief in the power of supernatural agencies still has a strong influence on forest resource management in Amani oho. 
Fig. 3. Forest lots used for hunting and trapping in Amani oho territory.

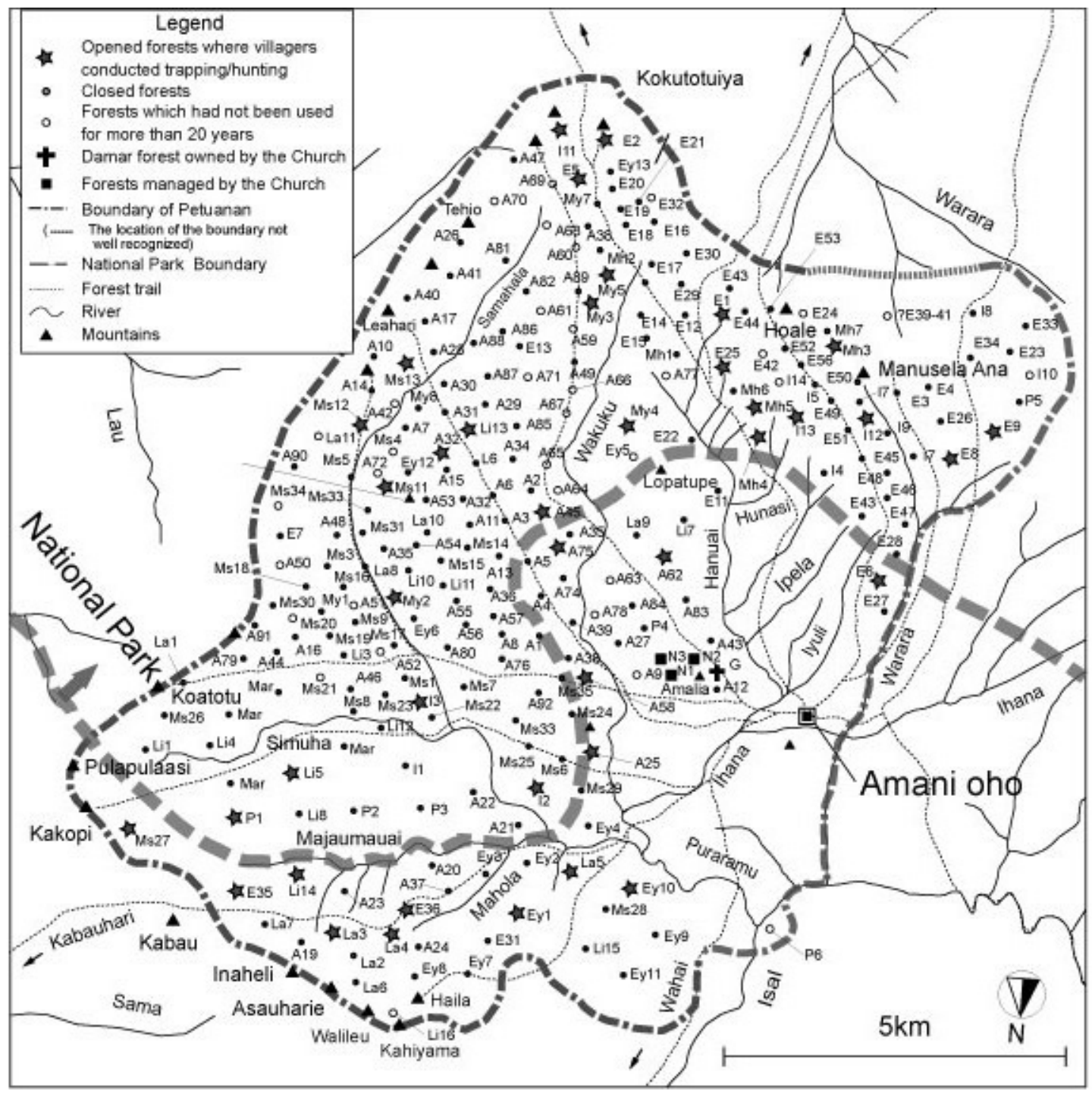

However, we observed recent transformations in local forest resource management such as the application of sasi gereja (church prohibitions) on forest resource use.

Sasi is a customary resource management system in the eastern part of Indonesia, encompassing spatial and temporal prohibitions on harvesting crops, cutting wood, and gathering other products from the forest, tidal zone, or marine territory of a village (Harkes and Novaczek 2002). In sasi gereja, the church plays the most significant role in imposing the prohibition, with a village clergyman publicly declaring the closing and opening of a certain area or resource. In Maluku, this type of sasi has become widespread among local Christian communities (Benda-Beckmann et al. 1995, Harkes and Novaczek 2002).
Christianity (Protestantism) was introduced to the upland areas of central Seram at the end of the 19th century. In Amani oho, almost all the villagers are Christians. However, their animistic beliefs coexist with their Christian beliefs.

Around the year 2000, some villagers started to implement sasi gereja to protect their own crops such as coconut, betel nut, and sago from others who might harvest them. Imposition of a sasi gereja must be requested from the village church council. The council is informed of the crops subject to the sasi and their location, a donation is made to the church, and the sasi is announced by the preacher during Sunday service. In the announcement, the preacher prays for a good harvest and admonishes the villagers not to infringe upon the sasi. The preacher also prays that if someone breaks the ban, the Christian God will inflict a punishment on them. 
Table 5. Forest lots closed by the imposition of seli kaitahu.

\begin{tabular}{|c|c|c|c|c|c|c|c|}
\hline Tenure form & Lohuno forest & Soa forest & Kin-group forest & Private forest & Discrepant $\dagger$ & Total & $\begin{array}{c}\text { Proportion } \\
(\%)\end{array}$ \\
\hline Forest under ban & 7 & 32 & 111 & 48 & 5 & 203 & 79 \\
\hline $\begin{array}{l}\text { Forest used as a trapping or } \\
\text { hunting site }\end{array}$ & 1 & 12 & 13 & 14 & 0 & 40 & 16 \\
\hline $\begin{array}{l}\text { Forest not used and not } \\
\text { subject to the ban }\end{array}$ & 0 & 3 & 0 & 0 & 0 & 3 & 1 \\
\hline Unknown & 0 & 1 & 9 & 1 & 0 & 11 & 4 \\
\hline Total & 8 & 48 & 133 & 63 & 5 & 257 & 100 \\
\hline
\end{tabular}

$\dagger$ Forest lots with disputed tenure status.

The sasi gereja is based on the local people's faith that if someone infringes upon the ban, they will be punished by the Christian God. In this respect, this type of resource management is based on a supernatural enforcement mechanism; thus, the sasi gereja and seli kaitahu have common characteristics.

A few villagers have started to adopt the sasi gereja instead of seli kaitahu for prohibitions on forest resource use. The following case is an example of the imposition of the sasi gereja on forest use by Ym. A., the village head of Amani oho.

Case 3: Ym. A. knew that someone had been hunting in his forest lots for several years, in violation of the seli kaitahu. In 2005, he imposed a sasi gereja on these forests and put up a notice on the forest trail stating that the forest was under sasi gereja. This was the first sasi gereja against forest use in Amani oho. The imposition of sasi gereja was not because Ym. A. no longer believed in the effectiveness of the supernatural power of seli kaitahu. However, Ym. A. explained that whereas ancestor and forest spirits may take some time to inflict a punishment on a seli kaitahu violator, the Christian God would punish a sasi gereja breaker shortly after the infringement. Ym. A. wanted the poachers punished as soon as possible. When the sasi gereja was lifted in December 2006, a half year later, his son-in-law found signs that someone had been hunting in violation of the ban. Ym. A. suspected $X$, who was a known poacher. $X$ and his wife had suffered from terrible malaria, and his brother had been seriously wounded by his machete. Ym. A. interpreted these misfortunes as punishments inflicted by the Christian God as a consequence of $\mathrm{X}$ 's violation of the sasi gereja. (Interviews with Ym. A., a 63-year-old male; Hs. Li., a 28-year-old male; and Yh. Li., a 36-year-old male, in February 2007).

\section{DISCUSSION}

The essential characteristic of the local forest resource management practiced in Amani oho is that supernatural agencies, rather than people, are expected to monitor resource use and inflict punishment on violators.
Recent commons studies have suggested that the ease and cost of monitoring resource user's behavior and enforcing rules have strong effects on the sustainability of resources (Stern et al. 2002). Formal institutions for resource management depend on a third-party legal structure, in which a regulatory agency often hires its own monitors and mediators. Such a regulatory structure may be expensive (Colding and Folke 2001).

By contrast, the forest resource management system in Amani oho does not burden the community with the high cost of monitoring resource use and enforcing the rules. Amani oho has $>250$ forest lots in its territory, and monitoring resource user's behavior in huge, forested areas would be difficult. Thus, the supernatural enforcement mechanism is fairly practical where the same cultural values and norms are widely shared by the community.

In addition, this resource management system, in which people do not directly accuse or punish violators, is suitable to the local sociocultural context. Local people have a strong fear of sorcery as an expression of the jealousy and discontent of others. Thus, they try to avoid discord within the community (Sasaoka 2008b). The fear of sorcery is not only the fear that one may be bewitched, but also that one might be suspected of practicing sorcery on others. If some ill feelings arise among villagers, it causes a constant fear of sorcery among them. It is likely that one of the main reasons that they strongly detest discord with others is to avoid such fear. As a result, local people avoid pointing out others' errors such as violations of seli kaitahu in face-to-face situations, and avoid directly inflicting punishment on those who break the rules.

This reluctance to directly address conflict was revealed in our one-on-one interviews with households. Where differing accounts of the history of forest rights inheritance and transfer arose, the villagers bitterly resented those who contradicted their own version. However, they showed no intention of resolving the discrepancy through direct dialogue and negotiation. They turned instead to complaining to their relatives without asserting the legitimacy of the recognition 
to their opponents face to face. Such conduct is assumed to create strong feelings of shame and anxiety.

In such a social-cultural context, even when someone violates the seli kaitahu, the owner of the forest is unlikely to attempt to identify the suspect and confront him because of the belief that this would lead to serious ill feelings. The supernatural enforcement mechanism serves to prevent discord among the villagers that may arise from the enforcement process because people do not directly accuse or punish the violator. This characteristic of the forest resource management system is highly suitable for the social-cultural context in which people have a strong disposition toward avoiding face-to-face accusations.

A few villagers in Amani oho started to apply sasi gereja to forest management in the mid-2000s. The head of the village, Ym. A., was the first to impose a sasi gereja on a forest in Amani oho. He was in a position to take the initiative in formulating a new forest resource management action against a series of seli kaitahu violations. However, he did not try to identify the violator; define new rules regarding forest use, monitoring, and sanctions; or form a management organization to enforce the rules. In sasi gereja, the Christian God took the place of the ancestor and forest spirits. Supernatural agencies still play a vital role in monitoring forest use and imposing sanctions on those who violate the rules. Instead of forming a more rational management system based on a social enforcement mechanism, he tried to reinstate the order of forest use by applying a new management system based on a supernatural enforcement mechanism supported by the people's belief in the Christian God. This initiative was suitable to the local social-cultural context because it did not require the local people to be directly involved in the process of enforcement.

The idea that if one violates seli kaitahu, then family members will surely meet with misfortune, is widely shared in Amani oho. Thus, it is uncertain that the sasi gereja will replace seli kaitahu as a norm controlling forest use. Unless this system is challenged by outsiders with different social-cultural backgrounds accessing their forests, the people of Amani oho are likely to maintain their well-structured forest use through their belief in supernatural agencies, even as the management system transforms.

\section{CONCLUSION}

In Amani oho, local people's belief in supernatural agencies is key to maintaining the forest resource management system. This supernatural enforcement mechanism is highly suitable in a social-cultural context in which people have a strong disposition toward avoiding face-to-face accusations and directly inflicting punishment on violators.

To promote self-directed resource management by people who coexist with supernatural agencies, such as the people of
Amani oho, it is necessary to reconsider the intervention of outside agencies such as government and nongovernment organizations. This includes national park management, which totally prohibits hunting and trapping and could disrupt the relationship between people and supernatural agencies. A new model of forest resource management needs to be constructed that is compatible with the local people's view of the supernatural world, taking cultural resilience and the actual ecological impact of the local resource management practices into consideration.

Responses to this article can be read online at: http://www.ecologyandsociety.org/issues/responses. php/5124

\section{Acknowledgments:}

Field research for this project was funded by the Japan Society for the Promotion of Sciences, during 2002-2004, and the Nagato Isao fund of the Society of Sago Palm Studies, in 2006. This publication was also made possible by grant assistance provided to the Center for International Forestry Research (CIFOR) by the Japanese Ministry of Foreign Affairs, in 2010, and by support from the Center for Social and Cultural Studies, Indonesian Institute of Sciences (PMB-LIPI); the Bureau of International Partnership, Forestry and Forest Products Research Institute (FFPRI); and the Collaborative Land Use Planning and Sustainable Institutional Arrangements for Strengthening Land Tenure, Forest and Community Rights in Indonesia (CoLUPSIA) project funded by the European Union. We thank these institutions and the project for their assistance and support. We also acknowledge Makoto Inoue (University of Tokyo), Aaron J. M. Russell (CIFOR), Karin Holzknecht (CIFOR), Glen Mulcahy (CIFOR), and Tomoya Akimichi (Research Institute for Humanity and Nature) for their valuable inputs to this article.

\section{LITERATURE CITED}

Benda-Beckmann, F., K. Benda-Beckmann, and A. Brouwer. 1995. Changing Indigenous environmental law in the central Moluccas: communal regulation and privatization of sasi. Ekonesia 2:1-38.

Berkes, F. 2008. Sacred ecology. Second edition. Routledge, New York, New York, USA.

Bhagwat, S. A., and C. Rutte. 2006. Sacred groves: potential for biodiversity management. Frontiers in Ecology and the Environment 4(10):519-524. http://dx.doi.org/10.1890/1540-9295 (2006)4[519:SGPFBM]2.0.CO:2

Byers, B. A., R. N. Cunliffe, and A. T. Hudak. 2001. Linking the conservation of culture and nature: a case study of sacred 
forests in Zimbabwe. Human Ecology 29(2):187-218. http:// dx.doi.org/10.1023/A:1011012014240

Colding, J., and C. Folke. 2001. Social taboo: "invisible" systems of local resource management and biological conservation. Ecological Applications 11(2):584-600. http:// dx.doi.org/10.1890/1051-0761(2001)011[0584:STISOL]2.0.CO;2

Etiendem, D. N., L. Hens, and Z. Pereboom. 2011. Traditional knowledge systems and the conservation of Cross River gorillas: a case study of Bechati, Fossimondi, Besali, Cameroon. Ecology and Society 16(3): 22. http://dx.doi. org/10.5751/ES-04182-160322

Hamilton, L. S. 2002. Forest and tree conservation through metaphysical constraints. George Wright Forum 19(3):57-78. [online] URL: http://www.georgewright.org/193hamilton. pdf.

Harkes, I., and I. Novaczek. 2002. Presence, performance, and institutional resilience of sasi, a traditional management institution in Central Maluku, Indonesia. Ocean \& Coastal Management 45(4-5):237-260. http://dx.doi.org/10.1016/ S0964-5691(02)00057-1

Kanto, Y. 2008. Conservation of the adat lands with religious function in Indonesia: a case of Bayan Village, Lombok Island. Journal of Environmental Sociology 14:170-184. [in Japanese]

Moniaga, S. 2007. From bmiputera to masyarakat adat: a long and confusing journey. Pages 275-294 in J. S. Davidson and D. Henley, editors. The revival of tradition in Indonesian politics: the deployment of adat from colonialism to indigenism. Routledge, London, UK.

Riley, E. P. 2010. The importance of human-macaque folklore for conservation in Lore Lindu National Park, Sulawesi, Indonesia. Oryx 44(2):235-240. http://dx.doi.org/10.1017/ $\underline{\mathrm{S} 0030605309990925}$

Saj, T. L., C. Mather, and P. Sicotte. 2006. Traditional taboos in biological conservation: the case of Colobus vellerosus at the Boabeng-Fiema Monkey Sanctuary, central Ghana. Social Science Information 45(2):285-310. http://dx.doi. org/10.1177/0539018406063644

Sasaoka, M. 2006. The meaning of "sago palm ownership": a monograph on the sago eater in a highland community in Seram, eastern Indonesia. South East Asian Studies 44 (2):105-144. [in Japanese] [online] URL: http://repository. kulib.kyoto-u.ac.jp/dspace/bitstream/2433/53847/1/KJ00004427985. pdf.

Sasaoka, M. 2008a. The economic importance of wildlife as a supplemental remedial source of income for remote mountain villagers in the tropics: a case study of commercial hunting of wild parrot in Seram Island, eastern Indonesia. Asian and African Area Studies 7(2):158-190. [in Japanese] [online] URL: http://repository.kulib.kyoto-u.ac.jp/dspace/ bitstream/2433/80112/1/aaas 7 158.pdf.

Sasaoka, M. 2008b. Wildlife use and the fulfillment of life: socio-cultural meanings of the subsistence use of game animals in a mountain village of Seram Island, eastern Indonesia. South East Asian Studies 46(3):377-419. [in Japanese] [online] URL: http://repository.kulib.kyoto-u.ac.jp/ dspace/bitstream/2433/84695/1/460302.pdf.

Stern, P. C., T. Dietz, N. Dolsak, E. Ostrom, and S. Stonich. 2002. Knowledge and questions after 15 years of research. Pages 445-489 in E. Ostrom, T. Dietz, N. Dolsak, P. C. Stern, S. Stonich, and E. U. Weber, editors. The drama of the commons. National Academy Press, Washington, D.C., USA.

Virtanen, P. 2002. The role of customary institutions in the conservation of biodiversity: sacred forests in Mozambique. Environmental Values 11(2):227-241. http://dx.doi. org/10.3197/096327102129341073

Wadley, R. L., and C. J. Pierce Colfer. 2004. Sacred forest, hunting, and conservation in West Kalimantan, Indonesia. Human Ecology 32(3):313-338. http://dx.doi.org/10.1023/B: HUEC.0000028084.30742.d0 